\title{
Technical Note: Disturbance of soil structure can lead to release of entrapped methane in glacier forefield soils
}

\author{
P. A. Nauer, E. Chiri, J. Zeyer, and M. H. Schroth \\ Institute of Biogeochemistry and Pollutant Dynamics (IBP), ETH Zurich, Zürich, Switzerland \\ Correspondence to: M. H. Schroth (martin.schroth@env.ethz.ch)
}

Received: 2 August 2013 - Published in Biogeosciences Discuss.: 6 September 2013

Revised: 13 December 2013 - Accepted: 17 December 2013 - Published: 4 February 2014

\begin{abstract}
Investigations of sources and sinks of atmospheric $\mathrm{CH}_{4}$ are needed to understand the global $\mathrm{CH}_{4}$ cycle and climate-change mitigation options. Glaciated environments might play a critical role due to potential feedbacks with global glacial meltdown. In an emerging glacier forefield, an ecological shift occurs from an anoxic, potentially methanogenic subglacial sediment to an oxic proglacial soil, in which soil-microbial consumption of atmospheric $\mathrm{CH}_{4}$ is initiated. The development of this change in $\mathrm{CH}_{4}$ turnover can be quantified by soil-gas profile analysis.

We found evidence for $\mathrm{CH}_{4}$ entrapped in glacier forefield soils when comparing two methods for the collection of soilgas samples: a modified steel rod (SR) designed for one-time sampling and rapid screening (samples collected $\sim 1 \mathrm{~min}$ after hammering the SR into the soil), and a novel multilevel sampler (MLS) for repetitive sampling through a previously installed access tube (samples collected weeks after accesstube installation). In glacier forefields on siliceous bedrock, sub-atmospheric $\mathrm{CH}_{4}$ concentrations were observed with both methods. Conversely, elevated soil- $\mathrm{CH}_{4}$ concentrations were observed in calcareous glacier forefields, but only in samples collected with the SR, while MLS samples all showed sub-atmospheric $\mathrm{CH}_{4}$ concentrations. Time-series of SR soil-gas sampling (additional samples collected 2, 3, 5, and $7 \mathrm{~min}$ after hammering) confirmed the transient nature of the elevated soil- $\mathrm{CH}_{4}$ concentrations, which were decreasing from $\sim 100 \mu \mathrm{LL}^{-1}$ towards background levels within minutes. This hints towards the existence of entrapped $\mathrm{CH}_{4}$ in calcareous glacier forefield soil that can be released when sampling soil-gas with the SR.

Laboratory experiments with miniature soil cores collected from two glacier forefields confirmed $\mathrm{CH}_{4}$ entrapment in these soils. Treatment by sonication and acidification re-
\end{abstract}

sulted in a massive release of $\mathrm{CH}_{4}$ from calcareous cores (on average $0.3-1.8 \mu \mathrm{g} \mathrm{CH}_{4}$ (g d.w.) ${ }^{-1}$ ) (d.w. - dry weight); release from siliceous cores was 1-2 orders of magnitude lower (0.02-0.03 $\mu \mathrm{g} \mathrm{CH}_{4}$ (g d.w.) ${ }^{-1}$ ). Clearly, some form of $\mathrm{CH}_{4}$ entrapment exists in calcareous glacier forefield soils, and to a much lesser extent in siliceous glacier forefield soils. Its nature and origin remain unclear and will be subject of future investigations.

\section{Introduction}

Methane in the atmosphere contributes significantly to global climate change (Forster et al., 2007). The total global $\mathrm{CH}_{4}$ budget is relatively well-constrained, but uncertainties in estimates of individual source and sink contributions remain high (Bousquet et al., 2006; Bridgham et al., 2013). About $70 \%$ of $\mathrm{CH}_{4}$ is from microbial sources (Conrad, 2009); other sources comprise fossil fuel extraction and mining $(\sim 18 \%)$ and biomass burning $(\sim 7 \%)$. There is still much debate about the contribution of plant-derived $\mathrm{CH}_{4}$ (Bruhn et al., 2012) and, recently, geologic sources (natural $\mathrm{CH}_{4}$ emissions related to hydrocarbon reservoirs or geothermal areas) have also been proposed to contribute significantly to the global budget (Etiope and Klusman, 2002, 2010; Milkov et al., 2003). Only three sinks of atmospheric $\mathrm{CH}_{4}$ have been identified: photochemical oxidation by $\mathrm{OH}$ radicals $(>80 \%)$, losses to the stratosphere, and oxidation by methane-oxidizing bacteria in unsaturated soils (Crutzen, 1991; Dutaur and Verchot, 2007).

In the wake of global change, glaciers and ice sheets have been subject to extensive investigations, resulting in the recognition of subglacial microbial life (Sharp et al., 1999; 
Skidmore et al., 2000, 2005). In this context, certain observations fueled speculations about widespread methanogenesis under ice, e.g. prevalent anoxic conditions under glaciers (Wadham et al., 2004), elevated $\mathrm{CH}_{4}$ concentrations in ice cores (Price and Sowers, 2004; Miteva et al., 2009), molecular evidence of the presence of methanogenic archaea (Miteva et al., 2009) and long-term incubation experiments (Boyd et al., 2010; Stibal et al., 2012). Potential climate feedbacks are subject of an ongoing debate, as the produced $\mathrm{CH}_{4}$ might be released with glacial meltdown (Wadham et al., 2008, 2012; Boyd et al., 2010).

Areas in front of receding glaciers, termed glacier forefields, are ecosystems created by glacial meltdown. With the ice melt causing a dramatic shift from a subglacial (anoxic, constantly cold, dark) to a proglacial habitat (oxic, temperature fluctuations, UV-light), organisms already present either adapt or disappear, while new organisms start to colonize the substrate. As exposure of subglacial sediments to the atmosphere occurs gradually, forming a well-defined soil chronosequence, glacier forefields are ideal environments to investigate soil development and microbial succession (Stevens and Walker, 1970; Sigler and Zeyer, 2002; Duc et al., 2009; Lazzaro et al., 2009, 2012). However, little is known of $\mathrm{CH}_{4}$ cycling in these environments.

Recently, microbial oxidation of atmospheric $\mathrm{CH}_{4}$ has been confirmed in glacier forefield soils in Greenland and Switzerland (Bárcena et al., 2010, 2011; Nauer et al., 2012). Methods employed to estimate soil- $\mathrm{CH}_{4}$ oxidation in the field included flux chambers and soil- $\mathrm{CH}_{4}$ profiles, respectively. Flux chambers should be inserted at least $5-10 \mathrm{~cm}$ into the soil to minimize lateral gas flux (Rochette and Bertrand, 2007; Rochette and Eriksen-Hamel, 2008). In the stony soil of a glacier forefield, finding locations where this is possible can be challenging and time-consuming. Hence, for the first survey on soil- $\mathrm{CH}_{4}$ oxidation in glacier forefields in the Swiss Alps (Nauer et al., 2012), the soil- $\mathrm{CH}_{4}$ profile method was employed using a steel rod (SR) designed for rapid soil-gas extraction in stony soils. Yet, repetitive sampling at the same location was not possible with this device. Consequently, a novel multilevel sampler (MLS) was developed for repeated soil-gas sampling at multiple depths (Nauer et al., 2013). Remarkably, elevated $\mathrm{CH}_{4}$ concentrations previously observed in SR samples from glacier forefields on calcareous bedrock could not be detected in samples from the MLS during initial tests.

Hence, our objectives for this study were (i) to compare the two sampling instruments (MLS and SR) side by side at three locations in a siliceous and a calcareous glacier forefield to confirm the disagreement with respect to elevated $\mathrm{CH}_{4}$ concentrations, (ii) to examine the possibility of temporary $\mathrm{CH}_{4}$ release during SR sampling by performing time-series sampling, and (iii) to provide a first quantitative assessment of potentially entrapped $\mathrm{CH}_{4}$ in glacier forefield soils by disturbing miniature soil cores in the laboratory using sonication and acidification.

\section{Materials and methods}

\subsection{Field sites}

Soil-gas samples and miniature soil cores were collected in two glacier forefields that were part of the initial survey on $\mathrm{CH}_{4}$ oxidation in the Swiss Alps (Nauer et al., 2012): the Damma Glacier forefield (DAM) on siliceous bedrock, and the Griessfirn Glacier forefield (GRF) on calcareous bedrock. Details on their soil-physical and chemical properties can be found in the literature (Lazzaro et al., 2009; Bernasconi et al., 2011; Nauer et al., 2012). In summary, soils in both glacier forefields ranged from barren glacial till to poorly developed Leptosols (IUSS Working Group WRB, 2006) with dominating sand and gravel fractions. Organic carbon and nutrient contents were low, but increasing with soil age. In each glacier forefield we sampled at three locations with increasing distance to the glacier. Location A was ice-free for $<20 \mathrm{yr}$, location $\mathrm{B}$ for $\sim 40-50 \mathrm{yr}$, and location $\mathrm{C}$ for $\sim 50$ 70 yr. Soils around location $\mathrm{A}$ at both sites and location $\mathrm{B}$ at GRF were largely devoid of vegetation, with occasional pioneer species such as Cerastium uniflorum at DAM, and Linaria alpina and Saxifraga aizoides at GRF. At location C at GRF we observed patchy ground cover of mainly Salix retusa and other creeping Salix spp. Location B and C at DAM came to lie in the "intermediate age section" as described in Bernasconi et al. (2011), and therefore exhibited similar vegetation cover and soil properties.

\subsection{Soil-gas sampling}

Collection of soil-gas samples was accomplished using the SR (Nauer et al., 2012) and the MLS as part of a newly developed sampling system (Nauer et al., 2013). A graphical overview of both instruments is given in the supporting information. The SR is a $2 \mathrm{~cm}$ diameter rod with an inner capillary to extract soil gas. It is hammered into the soil in userdefined increments and from each depth one soil-gas sample is collected, typically within $\sim 1$ min after hammering ceased. Conversely, the MLS is designed as an insert for perforated access tubes installed at least 2 weeks prior to soilgas sampling. With the MLS, up to 20 depths down to $1 \mathrm{~m}$ can be sampled through the access tubes wall, while an inflatable packer system seals the $5 \mathrm{~cm}$ interspace between the sampled depths.

The access tubes for the MLS were installed on 12 July 2012 at the GRF locations, and on 8 and 13 July 2012 at the DAM locations. Actual soil-gas sampling with the MLS took place on 25 July and 17 September 2012 at GRF, and on 31 July and 25 September 2012 at DAM. On the sampling days in September we subsequently sampled soil gas with the SR within $\sim 0.5 \mathrm{~m}$ distance from the installed access tubes at all locations (except for DAM C due to a sudden rain event). In addition to the typically collected single sample from each depth, we left the SR in place and collected another four 
soil-gas samples in sequence at $t_{\mathrm{n}}=2,3,5$ and $7 \mathrm{~min}$, respectively, after hammering ceased. Hence, a time-series of total $n=5$ samples were collected at each of the 3-4 selected depths (up to $65 \mathrm{~cm}$ ). The first samples from each depth at $t_{1}$ ( $\sim 1$ min after hammering ceased) were used for comparison with the MLS data, as they represented profiles equivalent to typically performed one-time sampling with the SR.

The procedure of soil-gas sampling was identical for both instruments. At the respective valve of the instrument we collected $15 \mathrm{~mL}$ soil gas with a plastic syringe (after discarding the respective dead volume) and injected it into previously evacuated $10 \mathrm{~mL}$ glass vials. Air from $2 \mathrm{~m}$ above ground was sampled in similar fashion. Pressure was measured with a manometer (LEO 1, Keller AG, Winterthur, Switzerland) to account for dilution and altitude-related concentration differences. Methane from all soil-gas samples was measured on a GC-FID as described in Nauer and Schroth (2010), while oxygen in selected samples was measured on a GC-TCD according to Urmann et al. (2007).

\subsection{Miniature-soil-core experiments}

To test soils from both glacier forefields in the laboratory for potentially entrapped $\mathrm{CH}_{4}$, we collected miniature soil cores on the day after respective sampling with the SR. At each of the SR sampling locations, a $60-70 \mathrm{~cm}$ deep and $\sim 50 \mathrm{~cm}$ wide soil profile was excavated. Soil cores were collected at 24-30 arbitrary spots along the profile using a small steel tube of $10 \mathrm{~mm}$ i.d. (inner diameter) and $80 \mathrm{~mm}$ length, which was horizontally driven $2-5 \mathrm{~cm}$ into the soil. We checked for compaction by comparing the insertion depth outside and core length inside the tube. Compacted cores were discarded on the spot, while cores with negligible compaction were immediately transferred into a $20 \mathrm{~mL}$ autosampler glass vial and sealed by crimped butyl rubber stoppers. To prevent microbial oxidation of potentially released $\mathrm{CH}_{4}$ we added $0.4 \mathrm{~mL}$ of acetylene $\left(\mathrm{C}_{2} \mathrm{H}_{2}\right)$ as inhibitor, resulting in a $\mathrm{C}_{2} \mathrm{H}_{2}$ gas concentration of approximately $2 \mathrm{v} / \mathrm{v} \%$. After transfer to the laboratory, $4-5 \mathrm{~mL}$ of $\mathrm{N}_{2}$ was added to each vial to create an overpressure, and the cores were stored at $8^{\circ} \mathrm{C}$ until further treatment.

To disturb the soil structure, cores in glass vials were subjected to two different treatments (addition of water with sonication, and acidification). Pressure and $\mathrm{CH}_{4}$ concentrations were measured before and immediately after each treatment to determine the mass difference of $\mathrm{CH}_{4}\left(\Delta \mathrm{CH}_{4}\right)$ in the vial's headspace. The initial mass of $\mathrm{CH}_{4}$ after closure in the field ( 0 -value field) was estimated using ambient pressure, temperature and $\mathrm{CH}_{4}$ concentrations in air on the day of sampling. The mass of $\mathrm{CH}_{4}$ in the headspace determined before the first treatment was denoted as 0-value lab. Five milliliters of ultrapure $\mathrm{H}_{2} \mathrm{O}$ was then added to each vial, followed by vigorous shaking of the vial for $30 \mathrm{~s}$ to suspend the soil core and to dissolve any water-soluble soil structure. Preliminary experiments showed that this had only marginal effects on
$\mathrm{CH}_{4}$ concentrations, therefore, the $\Delta \mathrm{CH}_{4}$ was determined after the following sonication treatment. For this the vials were submerged in an ultrasonic bath (USC500D, VWR International, Radnor, Pennsylvania, USA) and sonicated for $5 \mathrm{~min}$ at the highest level $(45 \mathrm{kHz}, 100 \mathrm{~W})$, to disrupt any loosely bound colloids or organic aggregates. Finally, we added $1 \mathrm{~mL}$ of $6 \mathrm{~N} \mathrm{HCl}$ to each vial to dissolve carbonate minerals and potential carbonate precipitates. The cores from GRF immediately released $\mathrm{CO}_{2}$; however, the acid was largely buffered within minutes. During the reaction, the headspace was connected to a $60 \mathrm{~mL}$ syringe, and the additionally produced gas volume was transferred to two empty and pre-evacuated $20 \mathrm{~mL}$ vials. Pressure and $\mathrm{CH}_{4}$ concentrations were determined together with the original vials to calculate total mass of released $\mathrm{CH}_{4}$. Five vials each of laboratory air and air with $2 \mathrm{v} / \mathrm{v} \%$ of $\mathrm{C}_{2} \mathrm{H}_{2}$ served as control and underwent the same treatments. Temperature was approximately $20^{\circ} \mathrm{C}$ during all laboratory experiments. Methane was determined as described above, but with additional runtime to allow for $\mathrm{C}_{2} \mathrm{H}_{2}$ elution.

\section{Results and discussion}

\subsection{Comparison of MLS and SR profiles}

In both glacier forefields, all $\mathrm{CH}_{4}$ concentrations measured in samples from the MLS were below atmospheric values (Fig. 1). The profiles from July and September generally agreed well and displayed no major discrepancies. Concentrations of $\mathrm{CH}_{4}$ showed a gradual decrease with depth, typical for soils with a stable soil- $\mathrm{CH}_{4}$ sink and no inherent $\mathrm{CH}_{4}$ source. The lowest $\mathrm{CH}_{4}$ concentrations were around $1 \mu \mathrm{LL}^{-1}$ in young soils (A locations), and tended to decrease to $0.5 \mu \mathrm{L} \mathrm{L}^{-1}$ in older soil (B and C locations). In contrast, SR samples collected $\sim 1 \mathrm{~min}$ after hammering ceased ( $t_{1}$; Fig. 1) showed elevated $\mathrm{CH}_{4}$ concentrations of up to $130 \mu \mathrm{LL}^{-1}$ at all GRF locations. These samples depict profiles comparable with one-time sampling with the SR (Nauer et al., 2012). Concentrations increased with depth, and highest values were reached at deepest sampling points. On the other hand, SR samples from DAM showed atmospheric or sub-atmospheric $\mathrm{CH}_{4}$ concentrations at all times (Fig. 1). In all SR samples $\mathrm{O}_{2}$ concentrations were between 98 and $100 \%$ of ambient air (not shown).

Clearly, elevated $\mathrm{CH}_{4}$ concentrations at GRF could not be explained by sample handling or analytical procedures, as for both sampling instruments the actual extraction of soil gas, storage and $\mathrm{CH}_{4}$ measurement were identical. Subatmospheric $\mathrm{CH}_{4}$ concentrations from siliceous sites showed that the SR did not "generate" $\mathrm{CH}_{4}$ by an unknown mechanism. Furthermore, we are confident that sampling with the MLS reflected steady-state situations, as suggested by various tests with the instrument (Nauer et al., 2013). Using the MLS the soil is not disturbed during sampling through access 


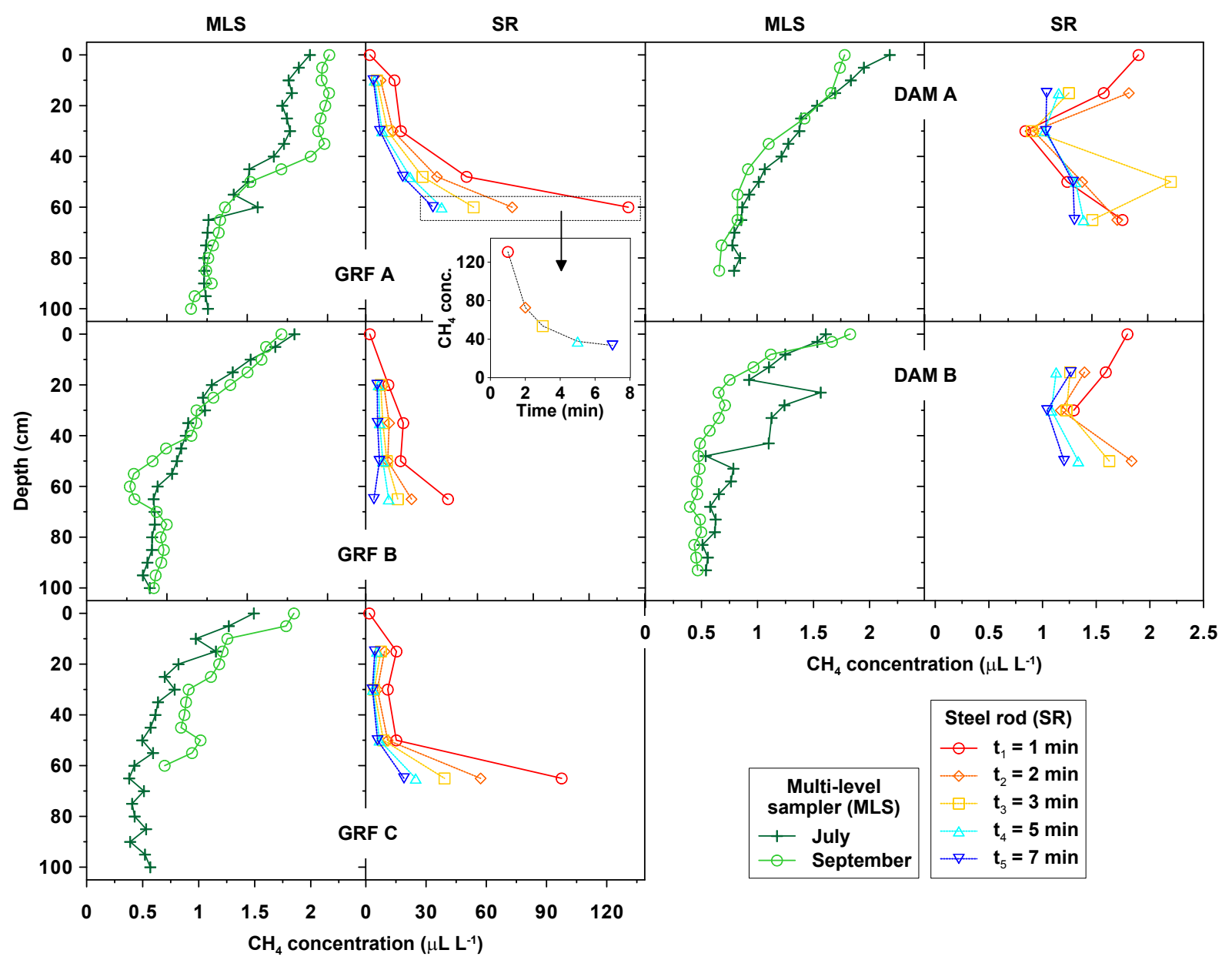

Fig. 1. Soil- $\mathrm{CH}_{4}$ profiles obtained from the MLS and the SR time-series soil-gas samples. The red SR samples $\left(t_{1}\right)$ can be directly compared to profiles for which each depth is sampled only once. Note the different scales of the $x$ axis for the SR profiles in GRF and DAM graphs.

tubes; disturbance occurs only once when the access tubes are installed (weeks earlier). Hence, the most probable explanation for the elevated $\mathrm{CH}_{4}$ concentrations in GRF soil is the momentary release of entrapped $\mathrm{CH}_{4}$ when hammering the SR into the soil.

\subsection{Time-series sampling with the SR}

At all GRF locations, elevated $\mathrm{CH}_{4}$ concentrations were decreasing exponentially within minutes when sampling several times at the same depth before hammering the SR to the next sampling depth (Fig. 1). This is likely a consequence of the incremental dilution due to sampling, as well as diffusive gas transport away from the release source (depicted in the insert of Fig. 1 with samples from GRF A at $60 \mathrm{~cm}$ depth). Possibly, concentrations immediately after hammering were even higher. This clearly shows that the elevated $\mathrm{CH}_{4}$ concentrations were transient and released by the act of sampling with the SR.
Time-series samples from DAM remained subatmospheric, with one exception at DAM A, $t_{3}$ (Fig. 1). However, $\mathrm{CH}_{4}$ concentrations tended to slightly increase with depth and decrease with time in the deepest samples. The variability of soil- $\mathrm{CH}_{4}$ concentrations between samples from the same depth was likely caused by soil heterogeneity and the increasing volume of soil gas extracted during repeated sampling. In GRF samples, potential variability was likely masked by the released $\mathrm{CH}_{4}$. However, it cannot be excluded that even in siliceous soils, small amounts of $\mathrm{CH}_{4}$ could be released by sampling with the SR.

With no additional information, the shape of the SR profiles $t_{1}$ from GRF might suggest a deep-soil $\mathrm{CH}_{4}$ source (Nauer et al., 2012), similar to what has been observed in landfills or peat bogs (Fechner and Hemond, 1992; Urmann et al., 2007; Schroth et al., 2012). However, given the transient nature of the elevated $\mathrm{CH}_{4}$ concentrations in samples from the SR, a steady-state interpretation of such soil-gas profiles involving a continuous source has to be rejected. More likely, as suggested by results from the MLS, glacier 


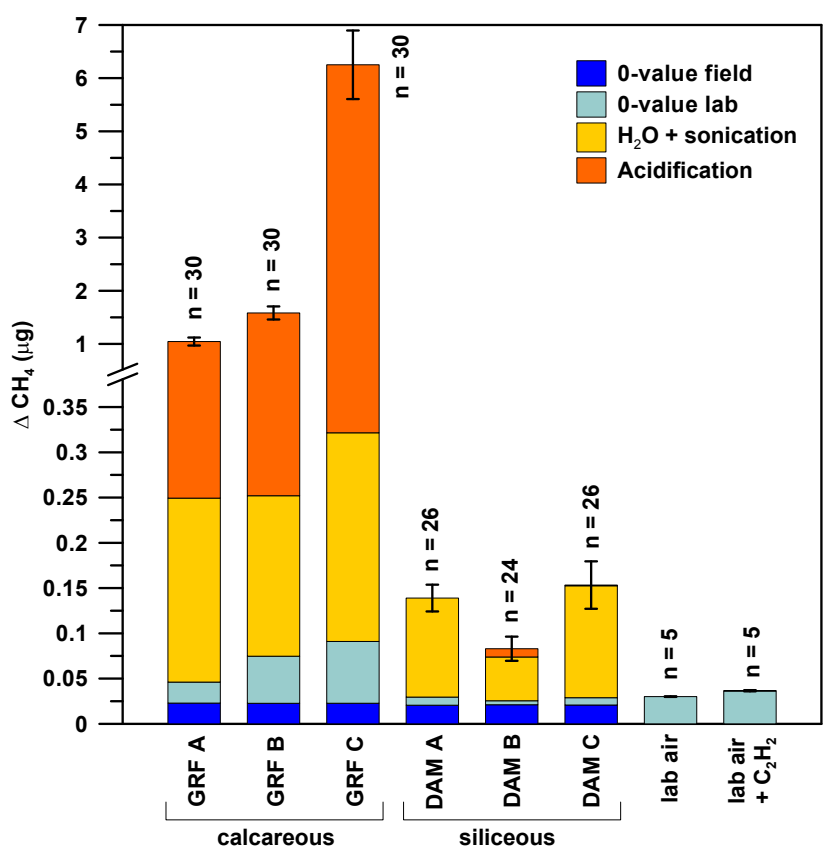

Fig. 2. Cumulative, average amount of $\mathrm{CH}_{4}$ released from miniature soil cores after treatments to disturb the soil structure. Note the break and variable scaling of the $y$ axis. Zero-values in the field represent the estimated amount of $\mathrm{CH}_{4}$ contained in enclosed ambient air; 0-values in the lab represent the (additional) amount of $\mathrm{CH}_{4}$ released during transport and storage. Error bars denote standard deviation of the mean of the total amount of $\mathrm{CH}_{4}$ in the vials.

forefield soils on both bedrock types appear to be stable sinks for atmospheric $\mathrm{CH}_{4}$. Nonetheless, the performed time-series sampling provided strong indications that additional $\mathrm{CH}_{4}$ from sources other than the atmosphere are retained in these fully oxic soils, whereby the amount present appears to be orders of magnitude larger in GRF compared with DAM soils. Considering the clear pattern reported in Nauer et al. (2012), where all SR samples from five calcareous glacier forefields showed elevated $\mathrm{CH}_{4}$ concentrations $\left(10-1000 \mu \mathrm{LL}^{-1}\right)$, the phenomenon of entrapped $\mathrm{CH}_{4}$ might be more widespread in these environments.

\subsection{Miniature-soil-core experiments}

For a first quantitative assessment of entrapped $\mathrm{CH}_{4}$, miniature soil cores enclosed in vials in the field were disturbed by different treatments in the laboratory, and the released $\mathrm{CH}_{4}$ was measured (Fig. 2). The average amount of $\mathrm{CH}_{4}$ released from cores of each location increased significantly during the course of the experiment, while in the control vials containing laboratory air or air $+\mathrm{C}_{2} \mathrm{H}_{2}$ it remained constant and even decreased marginally after acidification (decrease not visible in Fig. 2). Hence, cores from all locations contained some $\mathrm{CH}_{4}$ that was released with either sonication or both sonication and acidification.
However, the average amounts of $\mathrm{CH}_{4}$ released from calcareous soil cores were much higher than from siliceous cores (Fig. 2). Some of the GRF cores already released $\mathrm{CH}_{4}$ during transport from the field to the laboratory. It is unlikely that methanogenesis was ongoing in these cores as they were closed under oxic conditions. Rather we believe that $\mathrm{CH}_{4}$ was released when part of the core structure was disturbed. The addition of water itself had only a negligible effect (preliminary experiments, not shown), but sonication of the suspended cores released significant amounts of $\mathrm{CH}_{4}$ from DAM and GRF cores (2-5 times more from the latter; Fig. 2). This is a first indication that at least part of the $\mathrm{CH}_{4}$ could be entrapped in soil colloids or cemented particles that can be suspended by ultrasound. Acidification almost exclusively affected calcareous cores, for which the average amount of $\mathrm{CH}_{4}$ in the vials increased again by an order of magnitude or more (Fig. 2). Similar $\mathrm{CH}_{4}$ concentrations in the headspace of the vial containing the soil core and in the vials containing the excess gas volume showed that $\mathrm{CH}_{4}$ release from the core ceased once the added acid was buffered. As the acid affects all calcareous minerals, it is unclear from which particle fraction this massive $\mathrm{CH}_{4}$ increase originated. Likely, the acid foremost affected the smaller particle fractions in suspension, and only the surface of larger particles, before it was completely buffered. Although calcareous gravel ( $2-5 \mathrm{~mm}$ fraction) from another glacier forefield (Griessen glacier; Nauer et al., 2012) and a quarry showed $\mathrm{CH}_{4}$ release during acidification, total release was in the range of DAM cores (data not shown). This indicates that the bulk mass of $\mathrm{CH}_{4}$ in GRF samples may be entrapped in the finer soil fractions, e.g. in cemented particles. Clarification of this issue will require further investigation, which was beyond the scope of this study.

On a mass basis, $\mathrm{CH}_{4}$ in the vials from GRF increased on average by a factor of 45-270 compared to the originally enclosed air. This is roughly the same order of magnitude as the increase in soil-gas concentrations when sampling with the SR in the field. For DAM, the mass increase in the vials was in the range of 4-7, although no substantial increase in $\mathrm{CH}_{4}$ concentrations was observed with the SR in the field. Reasons for this are unclear; it might be attributed to the 1 min delay between disturbance (hammering) and sampling with the SR, which could be sufficient to dilute potentially released $\mathrm{CH}_{4}$ to ambient levels. However, it may also point towards a different nature of entrapment in siliceous versus calcareous soils.

When considering individual cores, cumulative amounts of released $\mathrm{CH}_{4}$ showed considerable variability (Fig. 3). Amounts released from GRF cores ranged from 0.12 to $7.5 \mu \mathrm{g} \mathrm{CH}$ (g d.w. $^{-1}$, which was $1-2$ orders of magnitude higher than the $0.002-0.16 \mu \mathrm{g} \mathrm{CH}_{4}$ (g d.w.) $)^{-1}$ from DAM cores. For the latter, the increase of $\mathrm{CH}_{4}$ in some vials was smaller than the estimated $\mathrm{CH}_{4}$ originating from the enclosed air. In contrast, all GRF cores released substantial amounts of $\mathrm{CH}_{4}$, but some "hotspots" were responsible for the most 


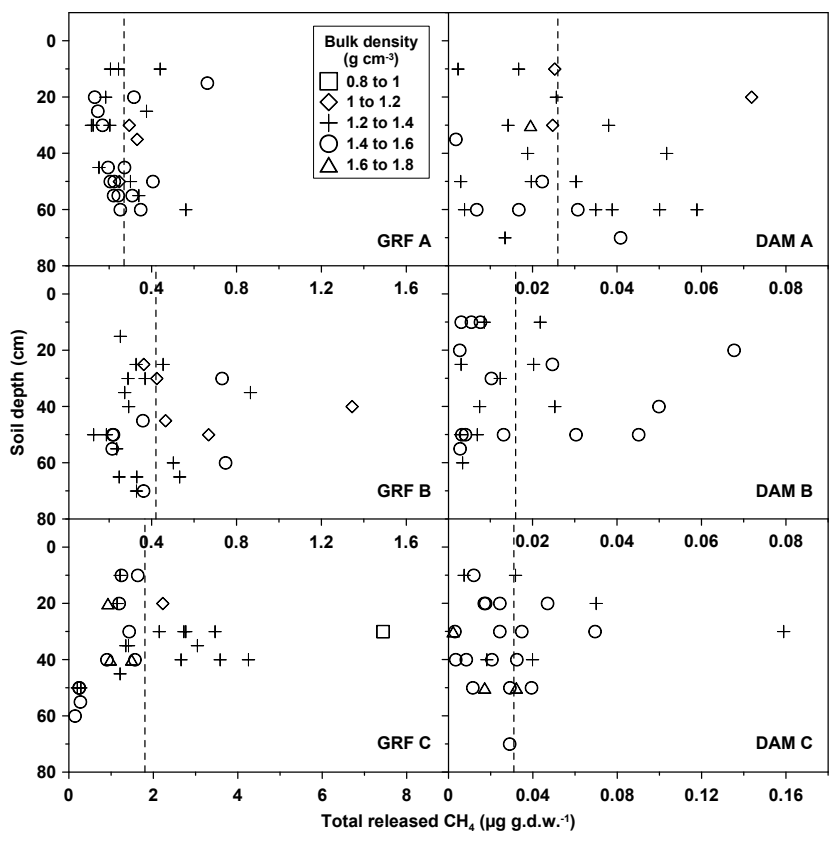

Fig. 3. Depth distribution and cumulative $\mathrm{CH}_{4}$ released from individual miniature soil cores. The different symbols denote bulkdensity classes of individual cores. Vertical dashed lines indicate the average cumulative $\mathrm{CH}_{4}$ release for each location.

pronounced increase. However, we could not observe a clear pattern of the released $\mathrm{CH}_{4}$ with respect to the sampling depth of the cores, with the exception of GRF B and C, where highest amounts of $\mathrm{CH}_{4}$ were released from samples collected around 30-40 cm depth (Fig. 3). Furthermore, there was no obvious correspondence with bulk-density classes. However, it is remarkable that the only sample with an exceptionally low bulk density released the highest amount of $\mathrm{CH}_{4}$ from all cores (Fig. 3, GRF C). At present, we lack a conclusive explanation for this observation.

\section{Implications for further studies}

In summary, we can state that there is $\mathrm{CH}_{4}$ entrapped in both the GRF and DAM soils, but the former retains orders of magnitude more $\mathrm{CH}_{4}$. In light of previous results (Nauer et al., 2012) our findings suggest that $\mathrm{CH}_{4}$ entrapment might be a common feature of glacier forefield soils, in particular on calcareous bedrock. At present, we can only speculate about the origin of released $\mathrm{CH}_{4}$ and the nature of entrapment. The observation that the bulk mass of $\mathrm{CH}_{4}$ appears to be entrapped in the finer soil fraction or aggregates could hint towards a potential role of secondary carbonate precipitates of glacial origin (Ford et al., 1970; Fairchild et al., 1993; Lacelle, 2007). Water films existing at the base of temperate glaciers can refreeze due to pressure changes while calcite precipitates and cements particles together (Fairchild et al.,
1993; Carter et al., 2003). Methane produced by subglacial methanogenesis may get entrapped in closed-off pores or fissures. Such a mechanism would partially prevent or delay the outgassing of any subglacially produced $\mathrm{CH}_{4}$ after glacial meltdown. Secondary carbonate precipitates have also been reported from environments on siliceous bedrock (Carter et al., 2003; Lacelle et al., 2007). However, it is unlikely that such precipitates would be preserved in the DAM soil with $\mathrm{pH}$ of 4-5 (Bernasconi et al., 2011). Here, other types of aggregates might be responsible for $\mathrm{CH}_{4}$ entrapment. In both glacier forefields, $\mathrm{CH}_{4}$ might also originate from recent methanogenesis in sealed microsites.

For calcareous glacier forefields we cannot exclude the possibility that the $\mathrm{CH}_{4}$ is entrapped in the bedrock itself. In this case the likely origin of the $\mathrm{CH}_{4}$ would be thermogenic. Sampled calcareous glacier forefields in Nauer et al. (2012) lie on late jurassic or early cretaceous limestones as part of the Helvetic nappes (Geological Atlas 1:500 000, Federal Office of Topography swisstopo, Wabern, Switzerland). The occurrence of these limestones partially overlaps with a zone where fluid inclusions in quartz-filled fissures are dominated by thermogenic $\mathrm{CH}_{4}$ (Mullis et al., 1994; Tarantola et al., 2007). In some adjacent marls in the Helvetic nappes, $\mathrm{CH}_{4}-$ dominated fluid inclusions in calcite-filled fissures have also been documented (Gautschi et al., 1990).

Further insights in the nature of these $\mathrm{CH}_{4}$ entrapments require additional experiments with fresh samples, including initial separation of grain-size classes, and complete dissolution of calcareous minerals to establish a total mass balance. Radiocarbon age determination and auxiliary stable isotope measurements may shed light on the origin of entrapped $\mathrm{CH}_{4}$. Furthermore, given the relative ease of how entrapped $\mathrm{CH}_{4}$ was released, its potential bioavailability should be addressed. Particularly in glacier forefields, $\mathrm{CH}_{4}$ diffusing from such entrapments could represent an additional source of carbon in an otherwise oligotrophic environment.

\section{Supplementary material related to this article is available online at http://www.biogeosciences.net/11/613/ 2014/bg-11-613-2014-supplement.pdf.}

Acknowledgements. Funding for this study by the Swiss National Science Foundation (grant no. 200021-137721) and by ETH Zurich (grant no. TH-20 06-3) is gratefully acknowledged. Thanks go to I. Erny and M. Vogt for their invaluable help with field work. Furthermore, we acknowledge the valuable inputs form H. Weissert, Dept. of Earth Sciences, ETH Zurich. Two anonymous referees are gratefully acknowledged for their contributions.

Edited by: E. Veldkamp 


\section{References}

Bárcena, T. G., Yde, J. C., and Finster, K. W.: Methane flux and high-affinity methanotrophic diversity along the chronosequence of a receding glacier in Greenland, Ann. Glaciol., 51, 23-31, 2010.

Bárcena, T., Finster, K., and Yde, J.: Spatial Patterns of Soil Development, Methane Oxidation, and Methanotrophic Diversity along a Receding Glacier Forefield, Southeast Greenland, Arct. Antarct. Alp. Res., 43, 178-188, 2011.

Bernasconi, S. M., Bauder, A., Bourdon, B., Brunner, I., Bünemann, E., Chris, I., Derungs, N., Edwards, P., Farinotti, D., Frey, B., Frossard, E., Furrer, G., Gierga, M., Göransson, H., Gülland, K., Hagedorn, F., Hajdas, I., Hindshaw, R., Ivy-Ochs, S., Jansa, J., Jonas, T., Kiczka, M., Kretzschmar, R., Lemarchand, E., Luster, J., Magnusson, J., Mitchell, E. A. D., Venterink, H. O., Plötze, M., Reynolds, B., Smittenberg, R. H., Stähli, M., Tamburini, F., Tipper, E. T., Wacker, L., Welc, M., Wiederhold, J. G., Zeyer, J., Zimmermann, S., and Zumsteg, A.: Chemical and Biological Gradients along the Damma Glacier Soil Chronosequence, Switzerland, Vadose Zone J., 10, 867-883, 2011.

Bousquet, P., Ciais, P., Miller, J. B., Dlugokencky, E. J., Hauglustaine, D. A., Prigent, C., Van der Werf, G. R., Peylin, P., Brunke, E. G., Carouge, C., Langenfelds, R. L., Lathiere, J., Papa, F., Ramonet, M., Schmidt, M., Steele, L. P., Tyler, S. C., and White, J.: Contribution of anthropogenic and natural sources to atmospheric methane variability, Nature, 443, 439-443, 2006.

Boyd, E. S., Skidmore, M., Mitchell, A. C., Bakermans, C., and Peters, J. W.: Methanogenesis in subglacial sediments, Environ. Microbiol. Reports, 2, 685-692, 2010.

Bridgham, S. D., Cadillo-Quiroz, H., Keller, J. K., and Zhuang, Q.: Methane emissions from wetlands: biogeochemical, microbial, and modeling perspectives from local to global scales, Glob. Change Biol., 19, 1325-1346, 2013.

Bruhn, D., Møller, I. M., Mikkelsen, T. N., and Ambus, P.: Terrestrial plant methane production and emission, Physiol. Plantarum, 144, 201-209, 2012.

Carter, C. L., Dethier, D. P., and Newton, R. L.: Subglacial environment inferred from bedrock-coating siltskins, Mendenhall Glacier, Alaska, US A, J. Glaciol., 49, 568-576, 2003.

Conrad, R.: The global methane cycle: recent advances in understanding the microbial processes involved, Environ. Microbiol. Reports, 1, 285-292, 2009.

Crutzen, P. J.: Methane's sinks and sources, Nature, 350, 380-381, 1991.

Duc, L., Noll, M., Meier, B., Bürgmann, H., and Zeyer, J.: High Diversity of Diazotrophs in the Forefield of a Receding Alpine Glacier, Microb. Ecol., 57, 179-190, 2009.

Dutaur, L. and Verchot, L. V.: A global inventory of the soil $\mathrm{CH}_{4}$ sink, Global Biogeochem. Cy., 21, GB4013, doi:10.1029/2006GB002734, 2007.

Etiope, G. and Klusman, R. W.: Geologic emissions of methane to the atmosphere, Chemosphere, 49, 777-789, 2002.

Etiope, G. and Klusman, R. W.: Microseepage in drylands: Flux and implications in the global atmospheric source/sink budget of methane, Global Planet. Change, 72, 265-274, 2010.

Fairchild, I. J., Bradby, L., and Spiro, B.: Carbonate diagenesis in ice, Geology, 21, 901-904, 1993.
Fechner, E. J. and Hemond, H. F.: Methane transport and oxidation in the unsaturated zone of a Sphagnum peatland, Global Biogeochem. Cy., 6, 33-44, 1992.

Ford, D. C., Fuller, P. G., and Drake, J. J.: Calcite Precipitates at the Soles of Temperate Glaciers, Nature, 226, 441-442, 1970.

Forster, P., Ramaswamy, V., Artaxo, P., Berntsen, T., Betts, R., Fahey, D. W., Haywood, J., Lean, J., Lowe, D. C., Myhre, G., Nganga, J., Prinn, R., Raga, G., Schulz, M., and Van Dorland, R.: Changes in atmospheric constituents and in radiative forcing, in: Climate Change 2007: The physical science basis, contribution of working group I to the fourth assessment Report of the Intergovernmental Panel on Climate Change, edited by: Solomon, S., Qin, D., Manning, Z., Chen, Z., Marquis, M., Averyt, K. B., Tignor, M., and Miller, H. L., Cambridge University Press, Cambridge, UK and New York, NY, USA, 2007.

Gautschi, A., Faber, E., Meyer, J., Mullis, J., Schenker, F., and Ballentine, C.: Hydrocarbon and noble gases in fluid inclusions of alpine calcite veins: implications for hydrocarbon exploration, Bulletin der Vereinigung Schweizerischer Petroleum-Geologen und-Ingenieure, 57, 13-36, 1990.

Lacelle, D.: Environmental setting, (micro)morphologies and stable $\mathrm{C}-\mathrm{O}$ isotope composition of cold climate carbonate precipitates - a review and evaluation of their potential as paleoclimatic proxies, Quaternary Sci. Rev., 26, 1670-1689, 2007.

Lacelle, D., Lauriol, B., and Clark, I. D.: Origin, age, and paleoenvironmental significance of carbonate precipitates from a granitic environment, Akshayuk Pass, southern Baffin Island, Canada, Can. J. Earth Sci., 44, 61-79, 2007.

Lazzaro, A., Abegg, C., and Zeyer, J.: Bacterial community structure of glacier forefields on siliceous and calcareous bedrock, Eur. J. Soil Sci., 60, 860-870, 2009.

Lazzaro, A., Brankatschk, R., and Zeyer, J.: Seasonal dynamics of nutrients and bacterial communities in unvegetated alpine glacier forefields, Appl. Soil Ecol., 53, 10-22, 2012.

Milkov, A. V., Sassen, R., Apanasovich, T. V., and Dadashev, F. G.: Global gas flux from mud volcanoes: A significant source of fossil methane in the atmosphere and the ocean, Geophys. Res. Lett., 30, 1037, doi:10.1029/2002GL016358, 2003.

Miteva, V., Teacher, C., Sowers, T., and Brenchley, J.: Comparison of the microbial diversity at different depths of the GISP2 Greenland ice core in relationship to deposition climates, Environ. Microbiol., 11, 640-656, 2009.

Mullis, J., Dubessy, J., Poty, B., and O’Neil, J.: Fluid regimes during late stages of a continental collision: Physical, chemical, and stable isotope measurements of fluid inclusions in fissure quartz from a geotraverse through the Central Alps, Switzerland, Geochim. Cosmochim. Ac., 58, 2239-2267, 1994.

Nauer, P. A. and Schroth, M. H.: In Situ Quantification of Atmospheric Methane Oxidation in Near-Surface Soils, Vadose Zone J., 9, 1052-1062, 2010.

Nauer, P. A., Dam, B., Liesack, W., Zeyer, J., and Schroth, M. H.: Activity and diversity of methane-oxidizing bacteria in glacier forefields on siliceous and calcareous bedrock, Biogeosciences, 9, 2259-2274, doi:10.5194/bg-9-2259-2012, 2012.

Nauer, P. A., Chiri, E., and Schroth, M. H.: Poly-use multi-level sampling system for soil-gas transport analysis in the vadose zone, Environ. Sci. Technol., 47, 11122-11130, 2013. 
Price, P. B. and Sowers, T.: Temperature dependence of metabolic rates for microbial growth, maintenance, and survival, P. Natl. A. Sci. USA, 101, 4631-4636, 2004.

Rochette, P. and Bertrand, N.: Soil-Surface Gas Emissions, in: Soil Sampling and Methods of Analysis, Second Edition, CRC Press, 2007.

Rochette, P. and Eriksen-Hamel, N. S.: Chamber Measurements of Soil Nitrous Oxide Flux: Are Absolute Values Reliable?, Soil Sci. Soc. Am. J., 72, 331-342, 2008.

Schroth, M. H., Eugster, W., Gómez, K. E., Gonzalez-Gil, G., Niklaus, P. A., and Oester, P.: Above- and below-ground methane fluxes and methanotrophic activity in a landfill-cover soil, Waste Manage., 32, 879-889, 2012.

Sharp, M., Parkes, J., Cragg, B., Fairchild, I. J., Lamb, H., and Tranter, M.: Widespread bacterial populations at glacier beds and their relationship to rock weathering and carbon cycling, Geology, 27, 107-110, 1999.

Sigler, W. V. and Zeyer, J.: Microbial Diversity and Activity along the Forefields of Two Receding Glaciers, Microb. Ecol., 43, 397407, 2002.

Skidmore, M., Anderson, S. P., Sharp, M., Foght, J., and Lanoil, B. D.: Comparison of Microbial Community Compositions of Two Subglacial Environments Reveals a Possible Role for Microbes in Chemical Weathering Processes, Appl. Environ. Microbiol., 71, 6986-6997, 2005.

Skidmore, M. L., Foght, J. M., and Sharp, M. J.: Microbial Life beneath a High Arctic Glacier, Appl. Environ. Microbiol., 66, 3214-3220, 2000.

Stevens, P. R. and Walker, T. W.: The Chronosequence Concept and Soil Formation, Q. Rev. Biol., 45, 333-350, 1970.
Stibal, M., Wadham, J. L., Lis, G. P., Telling, J., Pancost, R. D., Dubnick, A., Sharp, M. J., Lawson, E. C., Butler, C. E. H., Hasan, F., Tranter, M., and Anesio, A. M.: Methanogenic potential of Arctic and Antarctic subglacial environments with contrasting organic carbon sources, Glob. Change Biol., 18, 33323345, 2012.

Tarantola, A., Mullis, J., Vennemann, T., Dubessy, J., and de Capitani, C.: Oxidation of methane at the $\mathrm{CH}_{4} / \mathrm{H}_{2} \mathrm{O}-\left(\mathrm{CH}_{4}\right)$ transition zone in the external part of the Central Alps, Switzerland: Evidence from stable isotope investigations, Chem. Geol., 237, 329-357, 2007.

Urmann, K., Gonzalez-Gil, G., Schroth, M. H., and Zeyer, J.: Quantification of Microbial Methane Oxidation in an Alpine Peat Bog, Vadose Zone J., 6, 705-712, 2007.

Wadham, J. L., Bottrell, S., Tranter, M., and Raiswell, R.: Stable isotope evidence for microbial sulphate reduction at the bed of a polythermal high Arctic glacier, Earth Planet. Sc. Lett., 219, 341-355, 2004.

Wadham, J. L., Tranter, M., Tulaczyk, S., and Sharp, M.: Subglacial methanogenesis: A potential climatic amplifier?, Global Biogeochem. Cy., 22, GB2021, doi:10.1029/2007GB002951, 2008.

Wadham, J. L., Arndt, S., Tulaczyk, S., Stibal, M., Tranter, M., Telling, J., Lis, G. P., Lawson, E., Ridgwell, A., Dubnick, A., Sharp, M. J., Anesio, A. M., and Butler, C. E. H.: Potential methane reservoirs beneath Antarctica, Nature, 488, 633-637, 2012. 